\title{
WHAT'S WRONG WITH US? AN ANALYSIS OF INDONESIAN PRESIDENT JOKO WIDODO'S PUBLIC SPEECHES FROM 2017 TO 2018
}

\author{
Adam Tyson ${ }^{1 *}$ and Stanislaus Apresian ${ }^{2}$ \\ ${ }^{1,2}$ School of Politics and International Studies, Faculty of Social Sciences, \\ University of Leeds, United Kingdom \\ A.D.Tyson@leeds.ac.uk; ptsra@leeds.ac.uk
}

Received: $28^{\text {th }}$ April 2021/ Revised: $22^{\text {nd }}$ September 2021/ Accepted: $01^{\text {st }}$ October 2021

How to Cite: Tyson, A. \& Apresian, S. (2021). What's wrong with us? An analysis of Indonesian President Joko Widodo's public speeches from 2017 to 2018. Journal of ASEAN

Studies, 9(2), 219-239. https:/doi.org/10.21512/jas.v9i2.7318

\begin{abstract}
The research examines the rhetorical style and political priorities in Indonesian President Joko Widodo's public speeches during his first term in office. Content analysis is used to investigate a purposive sample of 66 presidential speeches from May 2017 to May 2018. In addition, the research identifies the similarity of words to understand the selective appraisal of Indonesia's progress based on President Jokowi's utterances. In one contentious oration on May 18 ${ }^{\text {th }}$, 2017, delivered to government officials, the president bluntly asked 'what's wrong with us'? The question presupposes that something is wrong in Indonesian politics, and is narrowcast to an audience of government officials, some of whom are implicated in the developmental shortcomings, administrative inefficiencies, and social conflicts that persist in Indonesia today. The president's strategic message implies that Indonesia's economic development unduly lags regional competitors; disinformation and hate speech create social divisions and political distortions; and there is a significant digital and technological divide in the country. The research result shows that the president's passion extends beyond bureaucratic reform and into contentious political topics, where selective attempts at disruptive truth-telling are made.
\end{abstract}

Keywords: presidential speechmaking; political rhetoric; truth-telling; Indonesia; Jokowi 


\section{INTRODUCTION}

In the aftermath of the 1997 Asian Financial Crisis Indonesia's longstanding, President Suharto resigned, and the country underwent a rapid transition to democracy. There have been four direct presidential elections since 2004. Joko Widodo, the current Indonesian President, was elected in 2014 and again for a second term in 2019, winning a repeat contest against Prabowo Subianto with 55,3\% of the popular vote. The research examines the rhetorical style and political priorities in Indonesian President Joko Widodo's public speeches from May 2017 to May 2018. The president's strategic messaging is often concerned with economic development, disinformation and hate speech, and the digital and technological divide in the country. The analysis shows that the president's conservative political outlook extends beyond bureaucratic reform and into contentious political topics, where selective attempts at disruptive truth-telling are made.

In one contentious speech delivered on May $18^{\text {th }}, 2017$, the president bluntly asked 'what's wrong with us' (apa yang salah dengan kita)? The question presupposes that something is wrong in Indonesian politics, and is narrowcast to an audience of government officials, some of whom are implicated in the developmental shortcomings, administrative inefficiencies, and social conflicts in Indonesia today. The research argues that this unconventional word choice is explained by context, given that a number of political crises were playing out in May 2017, and strategy, as the president seeks to push his selective reform agenda while maintaining his image as a hardworking, modest but ambitious leader focusing primarily on the national interest. Content analysis is used to scrutinize a purposive sample of 66 presidential speeches over a one-year period from May $18^{\text {th }}, 2017$ to May $17^{\text {th }}$, 2018 .

Evidence from Jokowi's first term in office suggests the president lacks a 'compelling political narrative' and has a vaguely formulated economic agenda (Tomsa, 2017). By analysing the content of presidential speeches, the research finds that the 'what's wrong with us' repertoire had been used repeatedly in the context of national development problems that persist through both presidential terms. The president appears to have strong views about what seems to hold Indonesia back, and why the country underperforms in certain sectors. Pessimism and optimism are interwoven in presidential speeches about national development and government performance, invoking Callahan's (2010) usage of the term pessoptimist in the Chinese context. Indonesia achieved a solid GDP growth rate of 5,07\% in 2017, and attracted much needed investment in infrastructure under Jokowi, although there are persistent problems such as budget inefficiencies and underperforming state agencies. ${ }^{1}$ The research does not attempt to measure the effect of presidential rhetoric on audiences. Instead, the content and central themes of a selection of presidential speeches from 2017 and 2018 are examined to gain insight into Jokowi's rhetorical style, as well as his public views on Indonesian society and the performance of his administration. 


\section{PRESIDENTIAL SPEECHMAKING}

As leader of the world's third largest democracy by population, President Jokowi's political speeches and rhetorical patterns have been regularly scrutinized in the media and by academics. In the age of social media, the character of public discourse is changing in complex ways (Ott, 2017), but the presidential speeches published by the Cabinet Secretariat in Indonesia remain to be important public records and communication artefacts. Technical studies of Jokowi's speeches focus on the general lack of coherence in his sentence structure that can be rectified through the use of images and graphs (Madkur, 2018); the president's preference for casual and plain language and his culturally Javanese style (Madkur, 2018; Siddiq et al., 2021); and his frequent use of positive connotations (Nurpadillah, 2017). It is essential to explore the reasons of Jokowi using such rhetorical patterns in the context of his changing political agenda.

This research reveals another side of Jokowi as a pessoptimist leader that has been generally overlooked by scholars such as Bland (2020), who writes the first English-language biography of Jokowi. Bland (2020) describes Jokowi as a leader full of contradictions, one who is reluctant to follow advice, is a pragmatist rather than an idealist, driven by action, not ideas, a businessman obsessed with small details but with good political instincts. As an ethnically Javanese leader, Jokowi is not always straightforward when delivering his political messages, adding another layer of ambiguity to his political character (Sumarsono, 2016).

During the 2014 presidential campaign, Hatherell (2014) finds that Jokowi deployed a performative kinerja repertoire, appealing to voters by highlighting qualities of hard work and effectiveness. This so-called kinerja repertoire can be found in Jokowi's speeches and gestures, underpinning his developmental priorities, infrastructure agenda and focus on administrative efficiency, a gambit that can backfire if Indonesia underperforms in certain sectors. Hatherell (2014) identifies Jokowi's repertoires of representation during his first presidential election campaign. However, further analysis of how Jokowi deals with Indonesia's underperformance is needed.

It is well-established that political leaders can manipulate their popularity ratings through drama and spectacle, including strategic speechmaking, with variable effects on policy agendas (Cohen, 1995). The theatrical and declaratory elements of presidential speeches can be used as a governance tool or bully pulpit to inspire or mobilize, to comfort or condemn (Shaw, 2017). President Jokowi is known as a man of many contradictions (Bland, 2020) who deploys multiple repertoires of representation for political gain (Hatherell, 2014). After a shaky start to his first term as president in 2014, Jokowi consolidated power in 2016 and enjoyed a surge in popularity (Warburton, 2016). The president is a pragmatist from Central Java province with a background in the furniture trade and a developmental agenda premised on efficiency, productivity, and infrastructure. Jokowi's speechmaking is often described as wooden and colourless apart from topics concerning bureaucratic streamlining and reform (Warburton, 2016). His campaign team and image consultants attempt to put his lack of charisma down to modesty (Tyson \& Purnomo, 2017). The analysis on Jokowi's speech rhetoric in 2017-2018 indicates that his passion extends beyond infrastructure and 
bureaucracy into contentious political topics, where he makes selective attempts at 'disruptive truth-telling' (Dey \& Mason, 2018).

Jokowi's indirect communication style echoes the Javanese tendency to avoid directly offending people. This indirect communication style is influenced by Javanese characteristics such as sopan santun or politeness, rasa rikuh or bashfulness, and empan papan as a form of conflict avoidance (Susetyo, Widiyatmadi, \& Sudiantara, 2014). Sumarsono (2016) reinforces the view that Javanese leaders are usually not straightforward and try to avoid direct communication if it offends other people. Considering this cultural trait, it makes sense that Jokowi engages in a form of disruptive truth-telling through speeches, making indirect, or vaguely attributable criticisms. As a pragmatic nationalist preoccupied with Indonesia's economic performance and material advancement, the president's speeches often allude to the superior performance of Indonesia's regional economic competitors such as China, Malaysia, and South Korea. As Jokowi contemplates the end of his second term in 2024 (Fealy, 2020), with the COVID-19 pandemic threatening his economic agenda and political legacy, the themes of his speeches from 2017-2018 remain being critical importance.

\section{METHODOLOGY}

The research utilizes content analysis to examine Jokowi's speeches, and generates quantitative data from written, spoken, and visual materials (Brancati, 2018). Speech transcripts and written materials are accessed through the Indonesian cabinet secretariat website. In constructing the quantitative data from speech transcripts, the researchers count certain words and phrases related to the May $18^{\text {th }}$ speech, such as 'what's wrong with us', and identify the similarity of words to understand the selective appraisal of Indonesia's progress based on Jokowi's utterances.

The research also investigates the president's rhetorical patterns by comparing his unpublished May $18^{\text {th }}$ speech with a sample of 66 presidential speeches addressing similar themes retrieved from the cabinet secretariat website over a one-year period from May 2017 to May 2018. A total of 165 speeches are reviewed, from which 66 are purposively selected because they address key national challenges related to economic development, media and technology, and social divisions. Content analysis of presidential speeches reveals Jokowi's pessoptimist view of politics and governance. This method helps establish speechmaking patterns and themes related to the May $18^{\text {th }}$, speech.

Jokowi's disruptive, rhetorical May 2017 'what's wrong with us' speech is unavailable on the Cabinet Secretariat's website, where official transcripts of presidential speeches are published. ${ }^{2}$ Jokowi's May $18^{\text {th }}$ speech is retrieved from YouTube and focus on the contents of the particular speech since it is unpublished, candid, and critical. Moreover, it is due to the timing and symbolic importance of the speech. ${ }^{3}$ In 2017 Indonesia's Corruption Eradication Commission (Komisi Pemberantasan Korupsi/KPK) was investigating a largescale graft case that involved Setya Novanto, then Speaker of the House, as well as other powerful public figures. The House of Representatives exceeded its parliamentary powers by 
holding inquiries into the KPK's general mandate and interfering in specific investigations, placing the president in the middle of a complex power struggle. At the same time, Islamist groups secured a controversial legal victory. Basuki Tjahaja Purnama, former governor of Jakarta and close political ally of Jokowi, was found guilty of blasphemy and crashed out of the Jakarta gubernatorial electoral contest (Tyson, 2021). As rival candidate, Anies Baswedan was sworn in as Jakarta's new governor in October 2017. Basuki Tjahaja Purnama was serving the first months of his two-year jail term in Mako Brimob Prison.

President Jokowi twice asks 'what's wrong with us' in his May $18^{\text {th }}$ speech. The formulation, along with related terms such as apa yang salah, apa yang keliru, ini keliru, and ini ada yang keliru, appear in 19 speeches between May 2017 and May 2018. This pattern suggests that the president is keen to involve broader audiences in the debate about national and sectoral progress in Indonesia. By using the term 'us' (kita), Jokowi seeks to share the burden of some of Indonesia's developmental failures and perhaps distance himself from these failures. NVivo software is used to calculate that the pronouns 'we' and 'us' appear 2411 times in Jokowi's speeches, while the word 'saya' or 'I' as the singular form of the first-person point of view appears 1575 times. 'We' implies a collective identity or general group membership, but can have different meanings in various contexts. Politicians can use 'we' in their speeches to achieve different effects, for instance: 1) to build institutional identity; to construct a dichotomy between 'us' and 'them'; 2) to deflect the attention of the audience away from particular issues; or 3) to invoke a general collective response related to a specific issue (Bramley, 2001). After counting the relevant words and identifying similarities to measure the speech transcripts using NVivo, the data is validated before moving on to data analysis process. For instance, 'wrong' appears frequently but may not be related to the 'what's wrong with us' narrative. Redundant words are eliminated from the data analysis process. All speeches are translated from Indonesian to English.

\section{POLITICAL BACKGROUND TO THE MAY $18^{\text {th }}$ SPEECH}

In 2014, Jokowi narrowly defeated Prabowo Subianto in a presidential race which involved 12 national parties (Aspinall \& Mietzner, 2014). A competitive multi-party democracy has taken root in Indonesia, a Muslim-majority country of more than 270 million people, along with robust independent institutions such as the Constitutional Court and the Corruption Eradication Commission (KPK). Jokowi's presidential victory in 2014 was significant due to his reputation as a hard-working reformist and relative political outsider who promised to fight corruption, improve the economy, and enhance the quality of governance and the bureaucracy (Tyson \& Purnomo, 2017). A furniture tradesman turned politician from Central Java, the president campaigned on a platform combining pro-poor policies with technocratic populism (Mietzner, 2017). Jokowi earned his reputation as a technocratic reformist during his time as mayor of Surakarta city from 2005-2012, and then as governor of Jakarta from 2012-2014. Economic policy under the Jokowi administration has attracted investment and infrastructure projects, although there is pushback from some protectionist state sectors and trade unions as opposed to deregulation (Ray \& Ing, 2016). 
On May $18^{\text {th }}$, 2017, when delivering his 'what's wrong with us' speech at the presidential palace, Jokowi insisted that the deputy head of the KPK, Alexander Marwata, be seated in the front row, which is usually reserved for ministers. He stated, "Before I begin this speech, I would like to ask for one more chair. I see the leader of the KPK. Mr. Alex, please come forward. The KPK is very important, do not place him at the back, he should be seated in front." At the time of Jokowi's address, some members of parliament had set up a special committee to inquire into the operations of the independent Corruption Eradication Commission (KPK), which was a formative challenge to one of the institutional pillars of Indonesia's post-1998 democratic system (Hiariej, 2017). The KPK uncovered a multimillion-dollar scandal related to the national e-identification program (e-KTP), in which former house speaker Setya Novanto and some parliamentarians were financially implicated. In 2018, Setya Novanto was sentenced to 15 years in prison for his role in the e-identification card graft case.

Another issue highlighted in the May $18^{\text {th }}$ speech was the mass rallies triggered by the blasphemy case of Basuki Tjahaja Purnama, the former governor of Jakarta (Tyson, 2021). The spread of disinformation and hate speech is a grave concern for the president. There were seven mass rallies related to the blasphemy case in Jakarta from 14 October 2016 to 5 May 2017 (Agustin, 2017). Jokowi laments the upsurge in 'unproductive' demonstrations linked to slander and blasphemy, where 'we' channel negative thinking and suudzon (an Arabic loanword meaning prejudice) towards others. On December $2^{\text {nd }}, 2016$ hundreds of thousands of protestors converged in Central Jakarta to demand the arrest of Governor Basuki Tjahaja Purnama, who in May 2017 was convicted of blasphemy under Article 156a of the Criminal Code. Religious organizations and the conservative Council of Indonesian Islamic Scholars issued legal opinions ( fatwa) denouncing the governor and mobilizing protests. The Purnama blasphemy case is symptomatic of the wider political struggles that Indonesia had to deal with during the president's first term.

Jokowi is known for running media savvy political campaigns, successfully projecting the image of a clean and humble candidate (Tapsell, 2015). However, since he took office in 2014, he has encountered smear campaigns, hoaxes, and rumours that aim to harm his credibility and stoke fears of sectarianism and religious strife. Jokowi has been branded a communist and a bad Muslim (Tyson \& Purnomo, 2017), while the president's disinterest in the human rights agenda and appointments of oligarchs and army generals to his cabinet cast doubt on his reformist credentials (Fealy, 2020). Transcending the somewhat dull and repetitive presidential speeches about bureaucratic streamlining and reform (Warburton, 2016), the content analysis of Jokowi's speeches in 2017-2018 shows that the president has a passion for contentious topics, selectively engaging in what Dey and Mason (2018) term disruptive truth-telling about complex topics in politics, business, and technology.

\section{CONTENTIOUS POLITICS}

There are many similarities between Jokowi's rhetoric in his unpublished May $18^{\text {th }}$ speech about social division caused by hate speech and subsequent speeches delivered 
between May 2017 and May 2018. This pattern shows that social division is considered by Jokowi to be one of the problems stunting the country's progress. Jokowi refers to 'fitnah' or smear four times, 'hujat' or blasphemy three times, 'menyalahkan' or blame four times, and 'menjelekkan' or vilify 14 times. The tone of the rhetoric is often pessimistic and includes forms of disruptive truth-telling by mentioning, for instance, that Indonesia wastes a lot of energy and national budget to provide crowd control for protests (SETKAB 3 June 2017).

Indonesia's national motto is unity in diversity (Bhinneka Tunggal Ika), and the president often claims to believe that cultural diversity should be regarded as a point of national pride. In speeches about religious inclusivity, for instance, the president claims that many foreign leaders have respect for Indonesia's pluralism and diversity, although Jokowi acknowledges that there are unresolved ethnic and religious tensions since the country's declaration of independence in 1945 (SETKAB 23 May 2017). Jokowi claims that these are politically motivated tensions actively exploited by groups to serve their interests and warns of the destabilizing effect of disinformation. During a June 2017 Pancasila Day commemoration, where Indonesia's five founding principles ${ }^{4}$ are celebrated, Jokowi asserted that one of the main challenges to national unity and integrity is the dissemination of fake news and hoaxes (SETKAB June $1^{\text {st }}, 2017$ ). Left unchecked, the spread of disinformation increases the risk of radicalism, intolerance, and discrimination becoming normalized in Indonesia, which directly contradicts the spirit of Pancasila.

While holding a press conference in June 2017 at Muhammadiyah University Malang, the president remarked upon the country's relative instability. The government and the police are facing public demonstrations provoked by the spread of fake news and hate speech (SETKAB June $3^{\text {rd }}, 2017$ ). Jokowi addressed widespread rumours about the re-emergence of the Indonesian Communist Party, repeatedly asking rhetorical questions such as 'where are they [the communists]', and 'how are they still around'? He added that the communists 'were dismissed when I was three years old [in 1965]' and he could have gone further by stating that there are basically no communists left in Indonesia. It is possible that president raised this issue in response to growing accusations that he is a communist sympathizer. The reproduction of communist imaginaries is a puzzling phenomenon in Indonesia today (Wadipalapa, 2020), given that the 1965 purge of the Communist Party and all affiliated organizations marked the definitive end of communism as a movement and ideology.

While marking the 60th anniversary of Padjadjaran University in Bandung, the president urged students to use their critical thinking capabilities to help foster an intellectual society that gives rise to beneficial innovations and public goods (SETKAB September $11^{\text {th }}$, 2017). Jokowi stated that rigid curriculums should not prevent students from thinking outside the box, as it has been the norm in the past for students to be restricted to their specialized area of study. Echoing his appeal to the teachers' union in July, Padjadjaran students who actively use social media were urged to combat the dissemination of fake news. Indonesia has a relatively high degree of online freedom, so users need to take responsibility for the prevention of fake news and hoaxes that undermine national unity by creating an atmosphere of uncertainty, mistrust, and intolerance (SETKAB September $11^{\text {th }}, 2017$ ). On September $14^{\text {th }}, 2017$, Jokowi officiated the opening of the National Library Service Facility Building in 
Jakarta, which is touted as the tallest library in the world. The president took the opportunity to discuss the general reading habits of Indonesians, stating that people spend too much time browsing social media content, while neglecting books and other reading materials in general (SETKAB September $14^{\text {th }}, 2017$ ). Ever the pessoptimist, Jokowi referred to social media's paradoxical tendency toward destructive innovation, where the ease of access to information contrasts with the tendency of Indonesian users to eschew facts and broadcast their biased views without proper evidence or academic research.

At the closing ceremony of the 2017 National University Leaders Conference in Bali, the president spoke proudly of Indonesia as a large, diverse, and tolerant nation (SETKAB September $\left.26^{\text {th }}, 2017\right)$. In the recent past, however, there have been inter-ethnic conflicts throughout the nation (Duncan, 2005), and Jokowi places heavy emphasis on the observance of the Pancasila ideology as a great unifier. One current challenge is the dissemination of provocative content through social media by competing interest groups that is changing public discourse. Much of this content is deemed anti-Pancasila and, according to the president, risks inflaming mass sentiments of hatred and intolerance. Jokowi stated that innovation in the digital age should produce positive development outcomes, as opposed to the 'destructive innovation' that occurs when social media is used as a tool of hatred and division (SETKAB September $26^{\text {th }}, 2017$ ). The same message was reiterated by Jokowi on National Teachers Day, which was celebrated in conjunction with the $72^{\text {nd }}$ anniversary of the Indonesian Teachers Association held in Bekasi (SETKAB December 2 ${ }^{\text {nd }}, 2017$ ).

While attending the Quranic Interpretation Council summit in his hometown Surakarta, Jokowi encouraged Islamic leaders and scholars (kyai, ulama) to be agents of national unity (SETKAB September 17 $7^{\text {th }}$ 2017). Radical interpretations of the Quran contribute to social and political instability in the post-1998 democratic era. Jokowi praises the solidarity that Indonesians hold for Muslims who are suffering in other parts of the world; however, he hopes that the same level of solidarity can be shared between countrymen and women. For example, in September 2017 the president hosted a gathering of 38 Islamic figureheads at the Independence Palace in Jakarta (SETKAB September 13 ${ }^{\text {th }}$, 2017). His speech focused on the humanitarian aid his government sent to the 370.000 or so Rohingya refugees in Bangladesh. Jokowi urged key religious figures to use their position and social status to spread positive messages, to help foster national unity without antagonizing their followers or indeed the government of Myanmar. This engagement with religious leaders took place in the same week that the Centre for Strategic and International Studies released a poll showing a $68,3 \%$ approval rating for Jokowi, so he was working from a position of strength (CSIS, 2017). One assumes that Jokowi's relative silence on the controversy in Xinjiang, China's Muslim majority province, relates to the growing trade, investment, and economic interdependence of Indonesia and China.

In addition to recruiting conservative cleric Ma'ruf Amin ahead of the 2019 elections, Jokowi has been building networks with mass Islamic organizations such as the modernist conservative Muhammadiyah and the pluralist interpretivist Nahdlatul Ulama. In September 2017, the president addressed a scout camp organized by the NU-associated Ma'arif Educational Institute, speaking to youths about the persistent challenges Indonesia faces as a 
nation, such as the dissemination of fake news, slander, and hate speech (SETKAB September $\left.18^{\text {th }}, 2017\right)$. Jokowi encouraged the scouts to actively combat these threats, as well as to participate in constructive and positive activities such as scout contests that challenge their creativity, physical fitness, and intelligence.

In the province of East Nusa Tenggara Jokowi officiated the launch of the Raknamo Dam that was completed in early 2018 by the Ministry of Public Works and Public Housing at a cost of some 760 billion rupiah. During his short stay, the president gave a public lecture at Muhammadiyah University Kupang, where he reflected on the virtues of diversity and pluralism (SETKAB January $8^{\text {th }}, 2018$ ). Sharing stories of his meeting with Afghan president Ashraf Ghani, Jokowi recalled how his counterpart marvelled at Indonesia's diversity, the hundreds of different ethnic groups that peacefully co-exist. Jokowi the pragmatic pessoptimist used this opportunity to warn students against complacency, as the country's fragile peace is put at risk by the spread of hate speech and online provocation. Beginning with the interjection waduh to express his disappointment, the president stated that people use social media to attack, reproach, accuse, and vilify one another, which is not a true reflection of Indonesian culture or tradition. ${ }^{5}$ The interrelated themes of national diversity (legitimized by Pancasila), the responsible use of new technologies, the spirit of innovation, integrity, and hard work feature prominently in all of the presidential speeches are reviewed in this research. Judging from Jokowi's rhetoric, however, he is still fighting an uphill battle and will continue to face resistance to change from within his government and bureaucracy.

\section{BUSINESS CLIMATE: WHY INDONESIA UNDERPERFORMS}

Economic performance is President Jokowi's primary political concern and policy agenda. He had to showcase steady economic growth to make the kinerja repertoire work for him to secure re-election in the 2019 presidential contest. He used the 'what's wrong with us' and 'tertinggal' or left behind rhetoric on many occasions to push government officials in improving economic performance. As a pragmatic, conservative culturally Javanese leader concerned mainly with Indonesia's economic growth and regional standing, there is a pattern of disruptive, pessimistic truth-telling in some of the president's speeches about the performance of Indonesia's regional economic competitors such as China, Malaysia, and South Korea. Jokowi referred Indonesia as being tertinggal (left behind) relative to China (sometimes called Tiongkok) 24 times in speeches, to Malaysia and South Korea 18 times respectively, to Vietnam and Singapore 12 times respectively, to India 11 times, Thailand 10 times, the Philippines 6 times, and Cambodia and Laos 3 times respectively. Accentuating Indonesia's economic shortcomings is a politically risky strategy, although Jokowi attempts to shape the narrative by presenting Indonesia's development problem as a collective problem. By asking 'what's wrong with us,' Jokowi invites the audience to share responsibility for and reflect on the causal factors for Indonesia's relative underperformance. The term tertinggal usually follows monoton or monotonous and rutinitas or routine, indicating that there is an entrenched problem with the bureaucratic working ethos. As a president whose branding includes the kinerja or performance repertoire, Jokowi is pushing 
government officials to improve efficiency and effectiveness, in what has been a relatively lethargic public administrative system.

Indonesia's 2017 GDP growth rate of 5,1\% is a good achievement, although the president consistently calls for improvements across the public sector. Despite a sound macroeconomic performance in Jokowi's first presidential term, Indonesia faces currency depreciation and the challenge of bureaucratic stultification (McLeod \& Rosdaniah, 2018), and the economy has suffered greatly as a result of COVID-19. Throughout 2017 and 2018 Jokowi highlighted government inefficiencies and made specific reference to several underperforming agencies, warning that Indonesia will fall further behind competitors if substantive changes are not made. In his May $18^{\text {th }}$ 'what's wrong with us' speech, the president cites budget inefficiency, maladministration, and a political culture of negativity as hindrances to Indonesia's development.

Based on comparisons with China, Malaysia, and South Korea, the president laments that Indonesia's development is less impressive than regional competitors. For instance, Jokowi compares the achievements of the Navy Shipyard Company (Penataran Angkatan Laut/PT PAL), an Indonesian state-owned enterprise in shipbuilding established in 1972, with the achievements of South Korean state-owned shipbuilders established in 1973. The president concludes that the sector in Indonesia is stagnating, whereas Korean companies have built globally competitive submarines. With reference to infrastructure and transport, the president stated, "...in the past [1970s], our toll road [Jagorawi] was a role model for other countries. But in 40 years we could only build 780 kilometres. China used to learn from us in the past, [but] they have built 280,000 kilometres". ${ }^{6}$ The critique of shipbuilding and transport infrastructure is a rhetorical form of disruptive truth-telling to pressure government officials to work harder and more efficiently.

Indonesia's relative malaise is contrasted with sectoral competitors who appear to be more adept at shaping and responding to technological change. Jokowi refers to major breakthroughs such as the internet, robotics, and artificial intelligence that are shaping the world around us and laments the fact that Indonesia, a youthful and populous country, is not a leading innovator. In his speech, the president praises Elon Musk (SpaceX, Tesla) as a key global trendsetter, and suggests that Indonesia is falling behind since so much of the nation's energy is misdirected, with constant public demonstrations and political gridlock.

Jokowi implores all ministries to improve the management of their budgets and to control spending so key performance targets can be met. Ever the pessoptimist, Jokowi questions why economic change moves so slowly. He points out that the nation resembles an athlete that is in good health, with low cholesterol, normal blood pressure, a healthy heart and lungs, and yet is still unable to run fast enough to win races (SETKAB January $5^{\text {th }}, 2018$ ). The analogy was repeated a few weeks later at the annual meeting of the financial services industry held in the Ritz-Carlton South Jakarta (SETKAB January $18^{\text {th }}, 2018$ ). Jokowi referred to Indonesia as a lumbering athlete at an investment meeting held at the State Palace in Jakarta (SETKAB January 23 ${ }^{\text {rd }}, 2018$ ). 
At a Ministry of Education and Culture meeting in Depok, Jokowi raised the issue of bureaucratic competence and called for greater efforts to improve human resources across the country (SETKAB February $6^{\text {th }}, 2018$ ). In addition, the country's poor performance relative to regional competitors is thought to stem from inefficient business licensing procedures, budget irregularities, uncoordinated local regulations, delayed infrastructure projects, and a general lack of innovation, among other factors. The president never seems tired of reminding his staff that the country has fallen behind Malaysia, the Philippines, and India in terms of foreign direct investment (SETKAB January $23^{\text {rd }}$, 2018). Jokowi argues that attracting foreign investment, for example through China's Belt and Road Initiative, will improve Indonesia's infrastructure projects and help ensure long-term national prosperity (SETKAB May 22 nd, 2017 ). Investor confidence is damaged, however, by Indonesia's unprofessional bureaucracy, particularly the irregularities that delay or complicate the issuance of business permits.

Economic problems are exacerbated by dysfunctional agencies and bureaucracies that deliver inaccurate forecasts such as rate of inflation estimates (SETKAB December $6^{\text {th }}$, 2017). During a speech at the Indonesian stock exchange, Jokowi emphasized that vital investment opportunities are lost due to poor administration and a lack of professionalism (SETKAB August $31^{\text {st }}, 2017$ ). According to the president, Indonesia needs an entire building dedicated to business permit processing to help attract investors, as well as to crackdown on bribery and mark-ups in government projects that deplete national budgets. The president expects every organization involved in government projects be more transparent in calculation for their expenditure, and that state-owned enterprises crackdown on unscrupulous and unprofessional practices such as nepotism, embezzlement, and subsidy mark-ups (SETKAB August $31^{\text {st }}$, 2017). Inter-departmental tensions and power struggles also perpetuate inefficiency, according to the president (SETKAB October 24 ${ }^{\text {th }}, 2017$ ). As a result, many of the president's speeches show that Jokowi is attempting to boost his image as a technocratic populist determined to clean up the political establishment, although there are deeply embedded conflicts of interest that undermine these efforts. ${ }^{7}$

Shortly after his inauguration, President Jokowi announced a flagship foreign policy called the Global Maritime Axis (Poros Maritim Dunia) that set out five principles to restore pride in the nation's archipelagic tradition (Nainggolan, 2015). For Indonesia to be a serious maritime power, the navy needs investment and strategic direction. Jokowi is working within a framework established by former president Susilo Bambang Yudhoyono known as the Minimum Essential Force that includes plans for naval modernization (Shekhar \& Liow, 2014). Naval procurement under this framework is necessary but contentious. Jokowi's May $18^{\text {th }} 2017$ critique on PT PAL, Indonesia's national shipbuilding company, was repeated the following month when he compared the inefficiencies of PT PAL to the South Korean Shipbuilding and Engineering Corp (now Daewoo, DSME). Found one year after PT PAL, DSME has vastly outperformed its Indonesian competitor (SETKAB June $3^{\text {rd }}, 2017$ ). ${ }^{8}$ DSME went private in 2000, and is now regarded as a world leading shipbuilding and offshore company. The Korean company is currently under contract to supply three DSME1400 class submarines to the Indonesian navy, at a cost of some US\$1.1 billion (Jung, 2017). 
Reflecting on his experience at the 2017 G20 summit in Hamburg, where Indonesia pledged to improve its tax administration system, Jokowi told the City Mayors and Regents Association at a conference in Malang that Indonesia still lags the other G20 members in terms of technology, economics, and infrastructure (SETKAB July 20 ${ }^{\text {th }}, 2017$ ). The audience reportedly fell silent as the president listed their shortcomings, but this did not discourage Jokowi, who went on to say that Indonesians should not resist change and should not be satisfied with the monotony of the status quo. Rapid technological developments in the G20 nations should inspire the creativity, innovation, and entrepreneurial spirit of the Indonesian people, which the country needs to survive (SETKAB July 20 ${ }^{\text {th }}, 2017$ ).

Blessed with natural beauty, diversity, and youthful energy, the Indonesian archipelago should be the top tourist destination in Southeast Asia, although this honour belongs to neighbouring Malaysia (SETKAB October $24^{\text {th }}, 2017$ ). Indonesia should be a world leader in coffee production, although it lags Brazil, Vietnam, and Colombia (SETKAB October $\left.1^{\text {st }}, 2017\right)$. Addressing a Ministry of Trade function in Jakarta, the president reiterated Indonesia's poor standing relative to export economies such as Thailand, Malaysia, and Vietnam, and warned that if the country does not shake off its inefficient routines it will be overtaken by Cambodia and Laos (SETKAB January 31 ${ }^{\text {st }}$ 2018). Jokowi's tone is pessimistic in this quote, but then shifts to an optimistic statement about Indonesia being the only Association of Southeast Asian Nations (ASEAN) member in the G20 in the same speech. As Jokowi told a gathering of diplomats at the Ministry of Foreign Affairs, Indonesia is a great country that should not feel inferior despite so often having a marginal presence at trade exhibitions in the global south (Bangladesh being one expo cited regularly by Jokowi), and so often being outperformed by regional rivals in terms of exports (SETKAB February $\left.12^{\text {th }}, 2018\right)$.

During a cabinet meeting in May 2017, Jokowi suggested that the mudik (annual return) that marks the end of Ramadan for Indonesia's Muslims presents a real logistical challenge. Each year millions of Indonesians return to their hometowns and villages, and the relative success of the mudik is a marker of just how far the government has achieved its goals in terms of infrastructure planning and building (SETKAB May 29 ${ }^{\text {th }}, 2017$ ). Another recurring test of the country's infrastructure and bureaucratic responsiveness is natural disaster management. When Mount Sinabung erupted in 2017, the president called for swift action to prevent a humanitarian crisis in North Sumatra, stating that inefficiencies and procrastination had, in the past, delayed the distribution of aid (SETKAB October $2^{\text {nd }}, 2017$ ). In terms of government spending more generally, Jokowi is very vocal about financial irregularities such as massive budget allocations disappearing, and he uses the mismanagement of the Mass Rapid Transit Jakarta project as a general indicator of Indonesia's slow infrastructure development (SETKAB May 23 ${ }^{\text {rd }}, 2017$ ). The unscrupulous handling of state budgets is endemic compared to neighbouring Singapore and Malaysia, according to the president, and Indonesia is falling further behind Vietnam and Thailand in terms of development. 


\section{THE DIGITAL AND TECHNOLOGICAL DIVIDE}

The third theme in Jokowi's speeches is the concern with the digital and technological divide. This is a common theme amongst ASEAN nations, for instance the highly publicised Thailand 4.0 model launched by the Thai government in 2017. In the speeches, Jokowi refers to social media 27 times, mobile internet 20 times, artificial intelligence 16 times, Tesla 10 times, and Elon Musk's controversial (and possibly failed) Hyperloop concept 10 times. Those words are mentioned to explain that the world is changing rapidly. If Indonesia does not catch up with other countries in the region, it will be left behind. The president also warned that social media platforms are really two sides of the same coin. New media and technology might bring positive effects such as expanding the digital market and improving education; however they are also used to spread hate speech and incite violence and terrorism.

Jokowi spoke at the opening ceremony of the 2017 Indonesia Business and Development Expo in Jakarta. The theme of the expo was the new economy in the digital age, and the importance of technological innovation as a driver of national development was stressed by the president (SETKAB September 20 $0^{\text {th }}, 2017$ ). As in his unpublished speech in May $18^{\text {th }}, 2017$, Jokowi singled out Elon Musk as a role model and pioneer. The recent leap in e-commerce in the new digital age means that Indonesian society has become more technologically dependent, with tech usage driven by the desire for convenience. Jokowi encouraged Indonesians to embrace this future, but at the same time to avoid negative, potentially incriminating media content online, as anything uploaded to the internet stays on the internet (SETKAB September 20 $0^{\text {th }}$ 2017). He added that such a heavy reliance on technology is changing work ethics and consumption habits. Jokowi put emphasis that this could be a threat to entrepreneurs' business, for instance, small businesses that do not adopt e-commerce practices often struggle to compete and face bankruptcy. Adding further nuance to the topic, recent research finds that Indonesia is still far from closing the digital divide, as feature phones with basic Internet services are used predominantly by older and less educated people, whereas younger smartphone users have faster and more sophisticated levels of information acquisition due to their access to advanced Internet services (Puspitasari \& Ishii, 2016).

In July 2017, the president addressed members of the Indonesian Teachers Union in Central Java. The importance of technological progress was the core message, but the president also warned of the negative effects of social media (SETKAB July 22 ${ }^{\text {nd }}, 2017$ ). Jokowi's pessoptimist view on social media combines praise for the speed of connectivity and innovation with reservations about the spread of hate speech, intolerance, and immoral content. Indeed, recent research points to the role social media plays in the 'rise of tribal nationalism in Indonesia' (Lim, 2017). At a social sciences forum in Solo Baru, one of the propositions was that Indonesians have grown too attached to mobile phones. The president stated that the nation's use of smartphones and social media platforms can be a force for good, although it can equally cause dissociative disorders and allow the dissemination of negative content (SETKAB August $9^{\text {th }}, 2017$ ). New technologies and smartphones are changing public discourses and the political landscape of the nation. Technology changes the 
way many people live, often creating positive outcomes and innovations, although public sector adaptation of technology is lagging, and has yet to improve efficiency (SETKAB August $\left.9^{\text {th }}, 2017\right)$. The president encourages Indonesian academies and education institutes to conduct new research on the effects of technological changes on society.

Attending the launch of a start-up conference called Indonesia Digital Byte at the Ritz-Carlton in Jakarta, the president reiterated that the country has stagnated and needed to base its development plans on value-adding innovation and new technologies (SETKAB September $\left.28^{\text {th }}, 2017\right)$. In addition to Indonesia's relative stagnation and dependency on imports, Jokowi warned that the misuse of new technologies and social media causes instability and 'destructive innovation'. Analysis of Indonesia's digital ecosystem suggests that online commerce accounts for at least US\$8 billion in consumer spending, with around $15 \%$ of the adult population shopping online (Das et al., 2018). To meet growth targets Indonesia must overcome challenges such as logistical bottlenecks, talent gaps, and inconsistencies in infrastructure and shipping standards, while encouraging cashless transactions and getting more businesses online (Das et al., 2018).

According to the president, there is an urgent need to address the issue of technological advancement for all government departments, in particular the Directorate General of Taxation. Inefficiencies and capacity issues within the bureaucracy continue to result in inaccurate tax statistics and data (SETKAB June 20 $\left.0^{\text {th }}, 2017\right)$. Bureaucratic inertia and the prevalence of bribery causes delays in the issuance of licenses and permits, which undercuts business and causes reputational damage (SETKAB July 27 $7^{\text {th }}$, 2017; SETKAB August $\left.20^{\text {th }}, 2017\right)$. The same concerns were raised during a session at the People's Consultative Assembly (Majelis Permusyawaratan Rakyat/MPR) on the eve of Indonesia's independence celebrations. Jokowi identified radicalism, corruption, and economic inequality as the major threats facing the nation (SETKAB August $16^{\text {th }}, 2017$ ). It is true that Indonesia needs less red tape and more innovation, as well as greater equality of opportunity, although a critique published the same day by Forbes suggests that Jokowi's basic diagnosis - the need for greater wealth distribution - is misguided (Worstall, 2017).

In terms of technology utilization to support economic activities, Indonesia seems to have fallen behind when compared to other countries in the region. Muhammad Nasir, the Minister of Research, Technology and Higher Education, revealed that Indonesia's research and development (R\&D) budget in 2015 comprised only $0,2 \%$ of GDP, behind South Korea $(4,3 \%)$, Singapore $(3,2 \%)$, and Malaysia $(1,1 \%)$ (Utomo, 2016). This comparison raises an important question about how Indonesia regards the role of technological research and development in the advancement of its economy. According to Ministry of Trade data, most of Indonesia's top ten commodities are resource and labour-intensive industries, such as textiles, natural rubber, palm oil, timber, footwear, shrimp, cacao, and coffee ("Produk unggulan Indonesia", n.d.). Only two out of the ten commodities, namely electronic appliances and automotive vehicles, are considered technology-based and capital-intensive industries. The dominant commodities for both categories are electronic and vehicle components, rather than the finished electronic appliances and vehicles ("Produk Ungglan Indonesia", n.d.). Indonesia's export commodities are in stark contrast with the export 
commodities of the newly industrialized countries (NICs). In China and South Korea, the top export commodities are technology-based sophisticated goods, for example cars, passenger and cargo ships, computers, telephones, and broadcasting equipment. According to World Bank figures from 2015, Indonesia's high-technology exports (US\$4,4 billion) lag South Korea, Malaysia, and Vietnam (each surpassing US\$30 billion) ("High-technology exports, n.d.). The comparison with Vietnam is particularly revealing. As a fellow developing country in Southeast Asia with prominent labour-intensive and resource-intensive industries, Vietnam managed to earn almost nine times more (US\$38,7 billion) than Indonesia from hightechnology exports in 2015 ("High-technology exports", n.d.).

To increase Indonesia's competitiveness in capital-intensive industries, Jokowi once played a formative role in promoting a student-built car brand called Esemka. When Jokowi was the mayor of Surakarta in 2012, he supported the local automotive industry by choosing Esemka as his official vehicle, however the popularity of Esemka has since declined. Jokowi acknowledged that, while it is government's duty to support production of Esemka cars, especially in passing certification and emission testing, it is up to the companies to design, manufacture, and market a successful indigenous automobile brand (Sani, 2018).

The current trappings of Indonesia's political economy dictate that the country focuses on labour-intensive and resource-intensive commodities with relatively low added value. For now, it may be the correct decision to keep fostering Indonesia's comparative advantage in these sectors, although Indonesia needs to compete with regional middle powers such as Vietnam that offers attractive low-cost production for investors and companies while gaining a lot from agricultural products and low-cost industries such as shoes and garments. In the long term, Indonesia expects to follow the developmental path taken by NICs such as South Korea, utilizing innovation and technology to fuel their economic rise. South Korea went from being one of the poorest countries in the 1960s to one of the world's largest and most dynamic economies due to its gradual shift from an agrarian economy to an urbanized, high-tech economy with a highly skilled workforce (Kyung-Sup, 2016). Indonesia announced its Global Maritime Axis policy and the president offers sober assessments of the country's competitive position, though Jokowi is torn between factions driving domestic political crises such as the KPK conflict and Purnama blasphemy trial. Indonesia's shipbuilders are unable to complete with the likes of Daewoo, which supplies the Indonesian navy. Therefore, while the government wishes to harness the potential of new information and communication technologies, it struggles to mitigate threats that arise from ICTs such as the spread of political hoaxes, disinformation, and religious incitement.

\section{CONCLUSIONS}

The research sheds light on a significant unpublished speech made by President Joko Widodo on May $18^{\text {th }}, 2017$, that reveals patterns of disruptive truth-telling on a selective and strategic basis. The twofold argument is that the president's unconventional word choice is explained: 1) by context, with several political crises playing out simultaneously in May 2017; and 2) by political strategy, as President Jokowi advances his ambitious reform agenda 
while attempting to maintain his branding as a humble but ambitious leader dedicated to Indonesia's strategic national interests. Considering the COVID-19 crisis, the themes that emerge in the analysis should remain front and centre of the presidential agenda and continue to set the tone for the remainder of Jokowi's second term that runs until 2024.

In 2017, Indonesia was deeply divided by the politicized and contentious blasphemy charges against former governor Basuki Tjahaja Purnama, institutional power struggles between the Corruption Eradication Commission, the House of Representatives, and the police, relative economic underperformance, and a stark digital divide. President Jokowi is not a transformational leader or charismatic orator. Rather, he seeks to use the power of his office to persuade and influence opinion, to pragmatically steer the country in what he believes to be the right direction. Economic growth, infrastructure, and bureaucratic efficiency are among the president's top priorities.

The research does not measure the effect of presidential rhetoric on audiences. Rather, it analyses a sample of presidential speeches to gain insight into Jokowi's rhetorical style as well as his nuanced views on Indonesian society. One notable pattern in his speeches is the tendency for Jokowi to downplay his own agency in the events he highlights. Considering Jokowi's re-election in May 2019, it is likely that the 'infrastructure president' will continue to pursue his economic development agenda, ramping up the rhetoric and accusations while strategically distancing himself from project delays and political conflicts. One of the most significant differences between Jokowi's first and second terms is the salience of Indonesia's foreign relations with China. During the 2019 election, the repeat challenger Prabowo Subianto ran a nationalist campaign and used China baiting and bashing to considerable effect, winning over many provincial constituencies outside Java. Prabowo accused the president of selling Indonesia out and of currying favour with their formidable East Asian neighbour. For instance, there is Indonesia's seemingly weak bargaining position as a recipient country in China's Belt and Road Initiative, as well as the contentious reclamation of the North Coast of Jakarta, the development of the Meikarta luxury apartment and business complex in Bekasi, the rapid train Jakarta-Bandung project, and the presence of Chinese mining companies in Sulawesi and Kalimantan.

The research investigates 66 presidential speeches and found that pessimistic and optimistic statements crossover in Jokowi's speeches, sometimes even appearing together in the same contradictory sentence. 'What's wrong with us' is a rhetorical device used on occasion by the president to justify his pessoptimist statements about Indonesia's economic or technological underperformance relative to regional competitors. The speech pattern is designed to provoke audiences to review their performances and ask hard questions about their achievements. As a pragmatic detail-oriented leader with sharp political instincts (Bland, 2020), Jokowi may be using an indirect communication style in keeping with his Javanese cultural manner and worldview, avoiding direct confrontation but still striving for a strategic and somewhat risky form of disruptive truth-telling that could backfire politically or pay long-term dividends. 


\section{NOTES}

${ }^{1}$ According to World Bank figures, Indonesian GDP was 5.18\% in 2018, 5.02\% in 2019, and then plummeted as a result of the COVID-19 pandemic.

2 There were 16 presidential speeches recorded by the Cabinet Secretary in May 2017. Official transcripts of presidential speeches are available online at http://setkab.go.id/category/transkrip-pidato/. All references to Jokowi's speeches obtained from the Cabinet Secretary website will be abbreviated and dated. For example, if it was on record, our reference to Jokowi's 'what's wrong with us' speech from 18 May 2017 would be cited as: (SETKAB May 18 $\left.{ }^{\text {th }}, 2017\right)$.

3 The full video of President Jokowi's May $18^{\text {th }} 2017$ speech is available at https://www.youtube.com/watch?v=R7aAtYIULmM

${ }^{4}$ Pancasila consists of five principles: belief in one supreme being (god), humanitarianism, national unity, consultation and consensus (governance), and social justice.

${ }^{5}$ The full quotation from 8 January 2018 reads as follows: Waduh, kalau coba lihat di media sosial itu, saling menyerang, saling mencela, saling menyalahkan, saling menjelekkkan. Saya kira hal-hal seperti itu bukan budaya Indonesia, bukan tradisi demokrasi di Indonesia.

${ }^{6}$ The 60-kilometre Jakarta-Bogor-Ciawi (Jagorawi) toll road was built in 1978. Indonesia's Toll Road Authority has signed at least 24 toll road concessions, but construction proceeds very slowly because of financial complications, budgetary constraints, and the complexity of land acquisitions (Sihombing et al., 2018). Jokowi repeated a number of these claims about Indonesia's relative underperformance in a speech to National Land Agency officials in Jakarta (SETKAB January $\left.10^{\text {th }}, 2018\right)$.

${ }^{7}$ For the April 2019 general election Jokowi's main catch-all campaign slogan was 'clean, with the people, and proven contribution' (bersih, merakyat, dan kerja nyata).

${ }^{8}$ For further analysis of Korean conglomerates (Jaebol) such as Daewoo, see Rhee (2005). 


\section{ABOUT THE AUTHORS}

Adam Tyson (corresponding author) is Associate Professor of Southeast Asian Politics at the School of Politics and International Studies, University of Leeds. He has published widely on contentious issues in contemporary Indonesian politics, with recent work on blasphemy trials and the environmental consequences of palm oil production.

Email a.d.tyson@leeds.ac.uk

ORCID 0000-0002-4458-6870

Stanislaus Risadi Apresian is a PhD Candidate in the School of Politics and International Studies, University of Leeds; an Assistant Professor at the Department of International Relations, Parahyangan Catholic University; and an awardee of the Indonesia Endowment Fund for Education (LPDP) Scholarship. His PhD thesis critically examines patterns of climate change adaptation, with evidence from Indonesia.

Email ptsra@1eeds.ac.uk

ORCID 0000-0001-9291-8334

\section{ACKNOWLEDGMENT}

We wish to thank Giasinta Livia for her assistance with this project. Giasinta is a Communication Support Specialist at UN Women.

\section{REFERENCES}

Agustin, D. (2017, May 10). Ini 7 rangkaian aksi bela Islam sebelum Ahok divonis 2 tahun penjara.

Republika. https://www.republika.co.id/berita/nasional/hukum/17/05/10/opp5r4330-ini-7rangkaian-aksi-bela-islam-sebelum-ahok-divonis-2-tahun-penjara

Aspinall, E. \& Mietzner, M. (2014). Indonesian politics in 2014: Democracy's close call. Bulletin of Indonesian Economic Studies, 50(3), 347-369. https://doi.org/10.1080/00074918.2014.980375

Bland, B. (2020). Man of Contradictions: Joko Widodo and the Struggle to Remake Indonesia. Victoria: Penguin Random House.

Bramley, N. R. (2001). Pronouns of politics: The use of pronouns in the construction of 'self' and 'other' in political interviews. (Unpublished $\mathrm{PhD}$ Thesis). Australian National University.

Brancati, D. (2018). Social Scientific Research. London: SAGE Publications Ltd.

Callahan, W. A. (2010). China: The Pessoptimist Nation. Oxford: Oxford University Press. 
Cohen, J. E. (1995). Presidential rhetoric and the public agenda. American Journal of Political Science, 39(1), 87-107. https://doi.org/10.2307/2111759

Centre for Strategic and International Studies (CSIS). (2017). 3 Tahun Jokowi: Kenaikan Elektoral \& Kepuasan Publik. Jakarta: Centre for Strategic and International Studies.

Das, K., Tamhane, T., Vatterott, B., Wibowo, P., \& Wintels, S. (2018, August 28). The digital archipelago: How online commerce is driving Indonesia's economic development. McKinsey \& Company. https://www.mckinsey.com/featuredinsights/asia-pacific/the-digital-archipelago-how-online-commerce-is-drivingIndonesias-economic-development

Dey, P. \& Mason, C. (2018). Overcoming constraints of collective imagination: An inquiry into activist entrepreneuring, disruptive truth-telling and the creation of 'possible worlds'. Journal of Business Venturing, 33(1), 84-99. https://doi.org/10.1016/j.jbusvent.2017.11.002

Duncan, C. R. (2005). The other Maluku: Chronologies of conflict in North Maluku. Indonesia, 80, 53-80. https://www.jstor.org/stable/3351319

Fealy, G. (2020). Jokowi in the COVID-19 era: Repressive pluralism, dynasticism and the overbearing state. Bulletin of Indonesian Economic Studies, 56(3), 301-323. https://doi.org/10.1080/00074918.2020.1846482

Hatherell, M. (2014). Repertoires of representation and an application to Indonesia's Jokowi. Representation, 50(4), 439-451. https://doi.org/10.1080/00344893.2014.980311

Hiariej, E. O. S. (2017, May 08). DPR Versus KPK. Kompas. https://nasional.kompas.com/read/2017/05/08/16582571/dpr.versus.kpk

High-technology exports (current US\$). (n.d). World Bank. https://data.worldbank.org/indicator/TX.VAL.TECH.CD?contextual=default\&end $=20$ $15 \&$ locations $=$ ID-VN-KR-MY\&start $=1988 \&$ view $=$ chart

Jung, M-H. (2017, August 02). DSME exports submarine named 'Nagapasa' for first time in Korea. Business

Korea. http://www.businesskorea.co.kr/news/articleView.html?idxno=18853

Kyung-Sup, C. (2016). Compressed modernity in South Korea: Constitutive dimensions, manifesting units, and historical conditions. In Youna Kim (Eds.), Routledge Handbook of Korean Culture and Society (pp. 31-47). London: Routledge.

Lim, M. (2017). Freedom to hate: Social media, algorithmic enclaves, and the rise of tribal nationalism in Indonesia. Critical Asian Studies, 49(3), 411-427. https://doi.org/10.1080/14672715.2017.1341188 
Madkur, A. (2018). A text analysis on President Joko Widodo's speech at APEC CEO Summit Asian Pacific. Pedagogy: Journal of English Language Teaching, 6(1), 1122. https://doi.org/10.32332/pedagogy.v6i1.1113

McLeod, R. H. \& Rosdaniah, S. (2018). An evaluation of some key economic policies. Bulletin of Indonesian Economic Studies, 54(3), 279-306. https://doi.org/10.1080/00074918.2018.1548245

Mietzner, M. (2017). Indonesia in 2016: Jokowi's Presidency between elite consolidation and extra-parliamentary opposition. Asian Survey, 57(1), 165-172. https://doi.org/10.1525/as.2017.57.1.165

Nainggolan, P. P. (2015). Kebijakan poros maritim dunia Joko Widodo dan implikasi Internasionalnya. Jurnal Politika, 6(2), 167-190.

Nurpadillah, V. (2017). Wacana kepemimpinan: Analisis makna konotasi dalam teks pidato perdana Presiden Jokowi. Jalabahasa, 13(1), 83-92. https://doi.org/10.36567/jalabahasa.v13i1.43

Ott, B. L. (2017). The age of Twitter: Donald J. Trump and the politics of debasement. Critical Studies in Media Communication, 34(1), 59-68. https://doi.org/10.1080/15295036.2016.1266686

Produk unggulan Indonesia. (n.d.). Ministry of Trade. http://ppei.kemendag.go.id/produkunggulan-indonesia/

Puspitasari, L. \& Ishii, K. (2016). Digital divides and mobile internet in Indonesia: Impact of smartphones. Telematics and Informatics, 33(2), 472-482. http://dx.doi.org/10.1016/j.tele.2015.11.001

Ray, D. \& Ing, L. Y. (2016). Addressing Indonesia's infrastructure deficit. Bulletin of Indonesian Economic Studies, $\quad$ 52(1), 1-25. https://doi.org/10.1080/00074918.2016.1162266

Rhee, J-C. (2005). The market's revolt in the dilemma between weak market capabilities and weak state capacities: The Korean case of corporate restructuring. Pacific Focus, 20(2), 241-275. http://doi.org/10.1111/j.1976-5118.2005.tb00293.x

Sani, A. F. I. (2018, October 24). Jokowi: Esemka car production not government's responsibility. Tempo. http://en.tempo.co/read/922831/jokowi-esemka-carproduction-not-governments-responsibility/full\&view $=$ ok

Shaw, K. (2017). Beyond the bully pulpit: Presidential speeches in the Courts. Texas Law Review, 96(1), 71-140. https://ssrn.com/abstract $=2981475$

Shekhar, V. \& Liow, J. C. (2014, November 07). Indonesia as a maritime power: Jokowi's vision, strategies, and obstacles ahead. Brookings. 
https://www.brookings.edu/articles/indonesia-as-a-maritime-power-jokowis-visionstrategies-and-obstacles-ahead/

Siddiq, A. A., Hidayat, D. N., Alek, \& Adrefiza. (2021). A text analysis on Joko Widodo's speech text on Indonesia's Independence Day. Linguistic, English Education and Art (LEEA) Journal, 4(2), 270-284. https://doi.org/10.31539/leea.v4i2.1708

Sihombing, L. B., Latief, Y., Rarasati, A. D., \& Wibowo, A. (2018). Project financing models for toll road investments: A state-of-the-art literature review. Civil Engineering and Architecture, 6(3), 115-127. https://doi.org/10.13189/cea.2018.060301

Sumarsono, H. R. (2016). Mengkritisi Aporisma Orang Jawa. Bekasi: Media Maxima.

Susetyo, D. P. B., Widiyatmadi, H. M. E., \& Sudiantara, Y. (2014) Konsep self dan penghayatan self orang Jawa. Psikodimensia, 13(1), 47-59. https://doi.org/10.24167/psiko.v13i1.277

Tapsell, R. (2015). Indonesia's media oligarchy and the 'Jokowi Phenomenon'. Indonesia, 99, 29-50. http://dx.doi.org/10.5728/indonesia.99.0029

Tomsa, D. (2017). Indonesia in 2016: Jokowi consolidates power. Southeast Asian Affairs, 149-162. https://muse.jhu.edu/article/658018

Tyson, A. (2021). Blasphemy and judicial legitimacy in Indonesia. Politics and Religion, 14(1), 182-205.

Tyson, A. \& Purnomo, B. (2017). President Jokowi and the 2014 Obor Rakyat controversy in Indonesia. Critical Asian Studies, 49(1), 117-136. https://doi.org/10.1080/14672715.2016.1258585

Utomo, Y. W. (2016, September 15). Dana riset jadi 0,2 persen PDB, tetapi cuma karena perubahan rumus penghitungan. Kompas. https://sains.kompas.com/read/2016/09/15/20481681/dana.riset.jadi.0.2.persen.pdb.tet api.cuma.karena.perubahan.rumus.penghitungan

Wadipalapa, R. P. (2020, September 29). Fabrikasi ingatan enam lima. Tempo. https://koran.tempo.co/read/opini/458303/opini-fabrikasi-ingatan-enam-lima-olehrendy-pahrun-wadipalapa

Warburton, E. (2016). Jokowi and the new developmentalism. Bulletin of Indonesian Economic Studies, 52(3), 297-320. https://doi.org/10.1080/00074918.2016.1249262

Worstall, T. (2017, August 16). Joko Widodo is in error here: Its more development Indonesia needs, not equality of poverty. Forbes. https://www.forbes.com/sites/timworstall/2017/08/16/jokowi-widodo-is-in-error-hereits-more-development-indonesia-needs-not-equality-of-poverty/\#48064e054e80 